\title{
Fixed assets reproduction and efficiency of their use in the context of the development of innovative and investment activities in the agrarian sector of the economy
}

\author{
Olga Sidorenko *, Elena Buraeva and Natalia Shabannikova
}

Orel State Agrarian University named after N.V. Parahin, Faculty of Economics, 19 Pobedy Boulevard, Orel, Russia

\begin{abstract}
The problem of increasing the efficiency of reproduction and use of fixed assets is relevant for the agrarian sector of the economy, since the material and technical base of agriculture requires technical modernization and renewal. The article analyzes security and quality of the fixed assets, the composition and structure of the sources of the fixed assets reproduction; the indicators of the efficiency of the fixed assets reproduction and their use are analyzed. Based on the results of the cluster analysis, groups of enterprises with the most optimal capital productivity indicators were identified, which served as the basis for determining the directions and reserves for increasing the efficiency of the fixed assets use in the agrarian sector of the economy.
\end{abstract}

\section{Introduction}

In modern times a crucial task in the development of organizations in the agrarian sector of the economy is to increase the volume of production of high-quality products, to enter the international food market. It is impossible to fulfill this task without introduction of new technologies, modernization and renewal of the material and technical base. In this regard, it is necessary to study the problems of reproduction and efficiency of using fixed assets in detail, as well as to determine the directions for enhancing investment activity.

Fixed assets reproduction is a continuous process of updating the material and technical base, including the stages of formation, restoration and retirement of fixed assets for maintaining them in the working order.

For agricultural organizations, the problem of the fixed assets reproduction is especially relevant, which is associated with a high level of physical wear and obsolescence of the fixed assets, annual reduction in the machinery and equipment fleet. With a lack of financial resources, low degree of capital investment development is observed in some regions.

The assessment of the state of the fixed assets reproduction should be carried out from the standpoint of an integrated approach to the analysis of indicators of security, quality

\footnotetext{
*Corresponding author: sov1974@mail.ru
} 
state, forms and sources of reproduction in order to determine the directions for increasing the efficiency of the fixed assets use.

Here special attention should be paid to the use of statistical and economic methods and, first of all, cluster analysis. This method makes it possible to divide the collection of the studied objects into homogeneous clusters, to identify groups of enterprises that have higher reproduction rates and the efficiency of using fixed assets.

The purpose of preparing a scientific article is to analyze the reproduction of fixed assets, determine the reserves for increasing the efficiency of the development of the material and technical base of the region, analyze the state of the investment process in the agricultural sector and develop proposals to improve the efficiency of innovation and investment activities of agribusiness entities.

\section{Material and methods}

The reproduction analysis is considered as an independent direction of the economic analysis, which has a system of indicators and a database. The main purpose of the reproduction analysis is to determine the reserves for increasing efficiency of the fixed assets reproduction and their use and the development of priority directions for enhancing innovation and investment activities.

The research was carried out in several stages: the analysis of security and quality condition of the fixed assets; the analysis of the composition and structure of the sources of the fixed assets reproduction; the analysis of the efficiency of reproduction and use of the fixed assets; identification of priority areas for the growth of capital productivity.

The clustering method with the application of the k-means clustering algorithm was used for a more detailed study of the capital productivity and its factors. The surveyed objects (organizations) are combined into homogeneous groups (clusters) according to the totality of the analyzed indicators using the method of cluster analysis. The process of clustering objects of the sampled population was performed using the Cluster Analysis tool of the STATISTICA package.

With regard to the study of the processes of the fixed assets reproduction, cluster analysis made it possible to determine effectively working groups of enterprises, which operating rates can serve as the basis for identifying ways and reserves for increasing the efficiency of the reproduction and use of the fixed assets, as well as enhancing innovation and investment in the agriculture.

\section{Results and discussion}

The development of the material and technical base is one of the priority tasks faced by the agricultural organizations. Therefore, the technical modernization of the agrarian sector of the economy based on the introduction of modern machinery is one of the most important directions of the state policy for the coming years. The analysis of the dynamics of the economic security indicators of the agricultural organizations, presented in Table 1, shows a positive tendency in the value increase of this group of assets. The dynamics of growth in the value of fixed assets is explained by the commissioning of new facilities, the acquisition of used fixed assets, and the free receipt of fixed assets. In addition, inflationary processes in the economy and changes in the value of assets as a result of revaluation influenced the growth in the value of fixed assets. The analysis of the dynamics of the fixed assets value is supplemented by an assessment of the energy capacity availability, which plays a leading role in the agricultural production. The study showed that the energy security per 100 
hectares of the agricultural land has slightly decreased, and the power-to-weight ratio increased by $7 \%$ due to a reduction in the number of employees.

Table 1. Dynamics of the economic security indicators of the agricultural organizations in 2017-2020.

\begin{tabular}{|l|c|c|c|c|}
\hline \multicolumn{1}{|c|}{ Indicators } & $\mathbf{2 0 1 7}$ & $\mathbf{2 0 1 8}$ & $\mathbf{2 0 1 9}$ & $\mathbf{2 0 2 0}$ \\
\hline $\begin{array}{l}\text { Fixed assets in the agricultural production, mln. } \\
\text { RUB }\end{array}$ & 54023 & 68654 & 78806 & 84914 \\
\hline Energy capacities, mln. hp & 1,5 & 1,6 & 1,6 & 1,6 \\
\hline $\begin{array}{l}\text { Capital intensity productive fixed capital, mln. } \\
\text { RUB/ 100 ha of the agricultural lands }\end{array}$ & 4,4 & 5,7 & 6,4 & 6,8 \\
\hline Capital-labor ratio, mln. RUB /1 person & 3,8 & 5,0 & 5,3 & 5,5 \\
\hline Energy security, hp/person & 177 & 173 & 179 & 171 \\
\hline $\begin{array}{l}\text { Power supply capacity, hp / 100 ha of the } \\
\text { agricultural lands }\end{array}$ & 96,2 & 99,2 & 101,6 & 103,7 \\
\hline
\end{tabular}

Analysis of the agricultural organizations security with the main types of the machinery revealed a downtrend in these indicators. At the same time, the problem of providing organizations with grain and sugar beet harvesters is especially relevant. Thus, the number of combine harvesters per 1000 hectares of grain crops is 2 units at a rate of 7.7 units, and the number of beet harvesters per 1000 hectares of crops is at the level of 1 unit at a rate of 12.5. The current situation leads to a load increment, which ultimately leads to the delay of the crop cultivation terms and yield decrease.

The qualitative state of the material and technical base is determined by the level of depreciation of fixed assets, the rate of renewal and write-off of worn-out objects, the average age by groups of fixed assets (Table 2).

Table 2. Indicators of movement and quality condition of the fixed assets of the agricultural organizations of the Orel region at the beginning of 2020.

\begin{tabular}{|l|c|}
\hline \multicolumn{1}{|c|}{ Indicators } & Indicator value \\
\hline Coefficient of renewal & 17,1 \\
\hline Retirement rate & 0,6 \\
\hline Fixed assets depreciation rate & 43,2 \\
\hline Liquidated fixed assets depreciation rate & 70 \\
\hline Relative share of the fully depreciated fixed assets & 9,3 \\
\hline Average age of the fixed assets, years: & 11,9 \\
- buildings & 7,5 \\
- structures & 7,7 \\
- machinery and equipment & 7,9 \\
- vehicles & \\
\hline
\end{tabular}

The analysis showed that the renewal rate was at the level of 17.1 , and the retirement rate (the ratio of retired fixed assets to the availability at the beginning of the year) was 0.6 , which indicated an intensification of the process of the fixed assets reproduction in the region, an increase in the material and technical base. Despite the active renewal of the material and technical base, the fixed assets depreciation rate is $43.2 \%$. A high level of depreciation can be associated with the operation of old fixed assets, first of all, their passive part (buildings, structures), as well as with the acquisition of previously operated facilities, failure to fulfill the plan for the commissioning of fixed assets and modernization of production [2].

The technical condition of fixed assets is characterized by their average age, which is calculated by types of groups of fixed assets. The performed analysis shows that in the region the longest service life for the buildings is11.9 years, the service life for structures is 
over 7.5 years. The age of the machinery and equipment employed in the agricultural production is 7.7 years, which can be assessed positively, since this group of the fixed assets is directly involved into the production process and rendering services and affects directly the financial results of the organization.

The amount of investment in the region as a whole and in the agricultural sector of the economy affects the level of the technical condition of fixed assets. We will analyze the dynamics of capital investments in agriculture in the article (Table 3).

Table 3. Dynamics of the volume of investments into the fixed assets aimed at the development of agriculture in the Orel region in 2010-2020.

\begin{tabular}{|c|c|c|c|c|c|}
\hline Indicators & $\mathbf{2 0 1 0}$ r. & $\mathbf{2 0 1 7}$ г. & $\mathbf{2 0 1 8}$ г. & $\mathbf{2 0 1 9}$ г. & $\mathbf{2 0 2 0}$ г. \\
\hline $\begin{array}{c}\text { Investments into the fixed } \\
\text { assets, mln. RUB }\end{array}$ & 2246,4 & 3990,4 & 7537,9 & 11082,7 & 10702,1 \\
\hline $\begin{array}{c}\text { As percentageof the } \\
\text { cumulative investment }\end{array}$ & 17,8 & 14,9 & 30,9 & 37,3 & 34,0 \\
\hline
\end{tabular}

The assessment of the dynamics and volume of the capital investments in the region shows that the total volume of the investments into the development of agriculture increased by $47 \%$ and amounted to 10702.1 million rubles in 2020.The investments into the agrarian sector of the economy amounted to $34 \%$ of the cumulative investment in the region. The growth of the capital investments volume is caused by the implementation of the strategy of technical modernization of agriculture and long-term investment projects with a large volume of capital investments in the region [3].

Currently, a number of important investment projects in the agriculture are being implemented in the Orel region. LLC "Orel-Agro-Product" is building a selection and seedbreeding center for the production of grass seeds in the Kromsky district of the Orel region. The cumulative investment will reach 1 billion rubles in 2018-2025. LLC "Agros" is building a grain processing plant with flour production and a grain warehouse with the cumulative investment of 250 million rubles. LLC "Agroindustrial Holding "Miratorg" is building pig farms and a feed factory with the cumulative investment of more than 25 billion rubles.

High rates of the fixed assets reproduction in the agribusiness entities cannot be achieved without sufficient provision of the investment process with financial resources. The assessment of the investment structure by the financing sources showed that the share of the inhouse sources in 2020 amounted to $26.7 \%$ of the cumulative investment. At the same time, the volume of thesourceof theborrowed funds increased up to $73.3 \%$. The share of bank lending increased in the total structure of the funding sources due to the growth in the volume of the soft investment lending. About $15 \%$ of investments into the fixed assets were financed by the depreciation. The depreciation should be not just an indicator reflecting the level of depreciation of the material and technical base, but the most important source of funding for the renovation process. Improvement of accounting and calculation of depreciation deductions, formation of an optimal depreciation policy of organizations, regular revaluation of the cost of fixed assets; the application of accelerated depreciation rates must be carried out. The practice of separately recording depreciation deductions and their subsequent investment in updating the production base, that is, creating a depreciation fund should be resumed. [4].

The efficiency of the fixed assets reproduction process is estimated by studying the ratio of the value of the produced and sold products, profit with the volume ofthe capital investments. The analysis of the efficiency indicators of the reproduction and use of the fixed assets is shown in Table 4. 
Table 4. Analysis of the efficiency indicators of the reproduction and use of the fixed assets in agricultural organizations.

\begin{tabular}{|l|c|c|c|c|c|c|}
\hline \multirow{2}{*}{ Indicators } & \multicolumn{5}{c|}{ Years } & $\begin{array}{c}\text { Absolute } \\
\text { variation }\end{array}$ \\
\cline { 2 - 5 } & $\mathbf{2 0 1 7}$ & $\mathbf{2 0 1 8}$ & $\mathbf{2 0 1 9}$ & $\mathbf{2 0 2 0}$ & \\
\hline \multicolumn{7}{|c|}{ Indicators of the efficiency of the fixed assets reproduction } \\
\hline $\begin{array}{l}\text { Specific capital investments per unit of the } \\
\text { fixed assets in use, RUB. }\end{array}$ & 0,1 & 0,2 & 0,3 & 0,6 & 0,5 \\
\hline $\begin{array}{l}\text { Capital productivity (RUB. revenue/RUB. } \\
\text { capital investment) }\end{array}$ & 15,8 & 11,4 & 6,5 & 6,6 & $-9,2$ \\
\hline Return on investment, \% & 8,0 & 5,6 & 3,1 & 2,1 & $-5,9$ \\
\hline \multicolumn{1}{|c|}{ Indicators of the effectiveness of the fixed assets use } \\
\hline Return on assets, RUB./100 RUB. & 65,6 & 66,2 & 62,5 & 85,8 & 20,2 \\
\hline Capital coefficient, RUB./100 RUB. & 152,3 & 151,0 & 160,0 & 116,4 & $-35,9$ \\
\hline Profitability of the fixed assets, \% & 33,2 & 32,8 & 30,1 & 27,8 & $-5,5$ \\
\hline
\end{tabular}

The study showed that the efficiency of the investments into the fixed assets remains rather low. The general reproduction ratio in 2020 was 0.6 , that is, the volume of the longterm investments exceeded the cost of the fixed assets introduced by more than $60 \%$. The indicators of the efficiency of the fixed assets reproduction are closely related to the indicators of the efficiency of their use, such as return on assets, capital coefficient and profitability of the fixed assets. The level of these indicators on average in the region is low. So the revenue from sales for 100 rubles of the fixed assets amounted to 85.8 rubles in 2020 , the profit was 27.8 rubles. This situation is explained by the outdistancing growth of the fixed assets value in comparison with the growth rates of revenues from sales and profit, with a long-term implementation of many investment projects. It is possible to evaluate positively the growth of return on assets, which increased in the analyzed period and amounted to 85.8 rubles $/ 100$ rubles.

Thus, in general, the process of the fixed assets reproduction in the Orel region can be assessed positively. In 2020, 10702.1 million rubles were allocated for the capital investments in the agriculture. About $70 \%$ of the investments were financed from the borrowed funds, that is, from loans and budget funds.

To determine the directions of increasing the efficiency of reproduction and use of the fixed assets, we used clustering analysis. According to the results of the cluster analysis, the collection of the studied enterprises is divided into 4 clusters according to the return on assets indicator:

Cluster 1 - enterprises with low return on assets (up to 60 rubles / 100 rubles)

Cluster 2 - enterprises with an average return on assets (61 - 90 rubles / 100 rubles);

Cluster 3 - enterprises with above average return on assets (91 - 120 rubles / 100 rubles);

Cluster 4 - enterprises with high return on assets (over 120 rubles / 100 rubles).

The average values of the studied characteristics and return on assets for each group of the enterprises are presented in Table 5.

An Assessment of the level of indicators shows that in all the identified clusters, the average share of the active part of fixed assets is over $50 \%$. The fact that the enterprises of 3, 4 clusters have current assets security, which is over 100 rubles per unit of the fixed assets, is positive. The expected value of the return on assets is determined by substituting the actual indicators (factor indicators) into the regression equation we have compiled $\left(\mathrm{Y}_{2}=40.56+0.16 \mathrm{x}_{1}-0.12 \mathrm{x}_{2}-0.13 \mathrm{x}_{3}+0.46 \mathrm{x}_{4}-0,12 \mathrm{x}_{5}+1.98 \mathrm{x}_{9}+0.31 \mathrm{x}_{11}\right)$. Comparison of the actual and calculated values of the revenue on assets showed that a significant part of the agricultural enterprises underutilizes the available opportunities to achieve the expected level of this indicator. In the first cluster group of the enterprises, the 
calculated value of the revenue on assets was formed at the level of 63.4 rubles, that is, only $44 \%$ of the level of the advanced enterprises (cluster 4).

Table 5. Clusters of enterprises by the level of capital productivity

\begin{tabular}{|l|c|c|c|c|}
\hline \multicolumn{1}{|c|}{ Indicators } & \multicolumn{4}{c|}{ Clusters (groups) of the enterprises } \\
\cline { 2 - 5 } & $\mathbf{1}$ & $\mathbf{2}$ & $\mathbf{3}$ & $\mathbf{4}$ \\
\hline Number of the enterprises in the group & 23 & 9 & 20 & 18 \\
\hline $\mathrm{X}_{1}$ - cost of products sold per 1 worker, thous. RUB. & 262,0 & 478,7 & 203,5 & 578,0 \\
\hline $\mathrm{X}_{2}$-fixed assets value per 1 worker, thous. RUB. & 476,6 & 691,5 & 205,5 & 440,5 \\
\hline $\begin{array}{l}\mathrm{X}_{3}-\text { share of the active part of the fixed assetsin their } \\
\text { overall value, \% }\end{array}$ & 51,9 & 67,6 & 51,0 & 59,2 \\
\hline $\mathrm{X}_{4}-$ degree of depreciation of the fixed assets, \% & 33,9 & 23,7 & 27,4 & 32,3 \\
\hline $\mathrm{X}_{5}$ - degree of renewal of the fixed assets, \% & 22,6 & 21,6 & 24,7 & 20,1 \\
\hline $\begin{array}{l}\mathrm{X}_{9}-\text { revenue from sales per 1 RUB. of the depreciation } \\
\text { charges, thous. RUB. }\end{array}$ & 2,2 & 2,7 & 7,5 & 5,4 \\
\hline $\begin{array}{l}\mathrm{X}_{11}-\text { the current assets value per 100 RUB of the fixed } \\
\text { assets, RUB. }\end{array}$ & 79,7 & 81,5 & 119,4 & 138,3 \\
\hline Actual value of therevenueonassets, RUB./100 RUB. & 55,0 & 69,2 & 99,0 & 131,2 \\
\hline $\begin{array}{l}\text { Expected value of the revenue on assets, RUB/100 } \\
\text { RUB. }\end{array}$ & 63,4 & 73,1 & 112,4 & 143,0 \\
\hline
\end{tabular}

Based on the results of the analysis performed, the following directions for improving the efficiency of using fixed assets have been identified:

- timely renewal of the fixed assets (the renewal rate must be at least $24 \%$ );

- ensuring rational proportions between the fixed and the current assets of the organization (per 100 rubles of the fixed assets there should be more than 100 rubles of the current assets);

- achieving optimal proportions between the active and passive parts of fixed assets; increasing the share of the active part of fixed assets and, first of all, machinery, equipment;

- improving the structure of funding sources due to the optimal ratio between own and borrowed sources;

- taking measures to restore fixed assets, that is, overhaul, reconstruction (modernization), in order to increase the production capacity of facilities;

- advanced training of working personnel, which contributes to a more efficient and careful handling of production equipment.

To increase the efficiency of reproduction, it is equally important to take measures to activate innovation and investment activities. In this direction, the following actions can be recommended for the agribusiness entities:

- formation of their own investment funds at the expense of the profit and depreciation charges by the agribusiness entities;

- strengthening the role of the depreciation charges in financing the fixed assets reproduction; application of the accelerated depreciation rates for the fixed assets employed in the innovative production;

- more active use of the leasing mechanism in the investment process, including innovative leasing, as a way of attracting and placing financial resources that provide innovative activity [1].

\section{Conclusions}

The research performed allows us to draw the following conclusions:

- The fixed assets reproduction is a continuous process of their updating for maintaining them in the working order. 
- Cluster analysis made it possible to single out groups of the enterprises by the level of their revenue on assets. The indicators of the enterprises' activity with the highest indicators of the efficiency of the use of the fixed assets served as the basis for identifying areas and reserves for the growth of the capital productivity.

- It is necessary to intensify innovation and investment activities in the agrarian sector of the economy, which will increase the rate of the renewal of the material and technical base and the efficiency of the reproduction processes.

\section{References}

1. Kussainova G., Saghaian S., Reed M. International Food and Agribusiness Management, 24 (2). 24, 2, 355 - 369. (2021), Available at: https://www.wageningenacademic.com/doi/epdf/10.22434/IFAMR2020.0016

2. Novotna M., Volek T. Efficiency of production factors and financial performance of agricultural enterprises. Agris online papers on economics and informatics. 4, 91 - 99. (2015), Available at: https://online.agris.cz/archive/2015/04/09.

3. Spicka J. International Food and Agribusiness Management Review: 21 (8). 21, 8, 1045 - 1059. (2018),

Available at:

https://www.wageningenacademic.com/doi/epdf/10.22434/IFAMR2018.0009.

4. Svoboda J., Lososova J., Zdenek R. Subsidies on investment in the EU member states. Agris online papers on economics and informatics, 4, 153 - 162 (2016), Available at: https://online.agris.cz/archive/2016/04/14. 